\title{
Profile of ocular and systemic characteristics in Möbius sequence patients from Brazil and Italy
}

\author{
Perfil de características oculares e sistêmicas de pacientes com a sequência de Möbius do Brasil e da Itália
}

Bruna Vieira Ventura ${ }^{1}$, Marilyn Tiller Miller ${ }^{2}$, Diana Danda ${ }^{1}$, Arturo Carta $^{3}$, Carlos Teixeira Brandi ${ }^{4,5}$, Liana Oliveira Ventura ${ }^{1,6}$

\begin{abstract}
Purpose: To compare the profiles and clinical findings of a series of patients with Möbius sequence from Brazil with a series from Italy. Methods: This is a multicenter study, which includes 46 Möbius sequence patients from Brazil and 20 from Italy. Socio-demographic, gestational, and neonatal profile characteristics were collected from interviews with the guardians of the Möbius sequence patients and compared. The Möbius sequence patients were submitted to an ophthalmologic examination and systemic malformations were also evaluated. Results: Misoprostol was used in the first trimester of pregnancy by 26 (56.5\%) of the mothers of the Möbius sequence patients in the Brazilian series and was not used by any of the Italian mothers. The mean age of the Brazilian Möbius sequence patients was $89.95 \pm 7.79$ months and the mean age of the Italian patients was $102.6 \pm 22.94$ months ( $P=0.6105$; MannWhitney test). Brazilian mothers had a significantly lower education level $(P=0.0002$; Fisher's exact test) and Italian mothers had significantly more stable relationships ( $p=0.0002$; Fisher's exact test). The frequency of ocular and systemic abnormalities was similar in both series. Conclusion: Adverse events during pregnancy varied between both groups. A history of misoprostol use during early pregnancy was present only in Brazilian mothers, who had lower levels of education and less frequent stable marital statuses. Clinical findings were similar between both groups of patients.
\end{abstract}

Keywords: Möbius syndrome; Misoprostol/adverse effects; Ocular motility disorder; Education; Brazil; Italy

\begin{abstract}
RESUMO
Objetivo: Comparar o perfil de características oculares e sistêmicas de uma série de pacientes com sequência de Möbius do Brasil com uma da Itália. Métodos: Esseestudo multicêntrico incluiu 46 pacientes com sequencia de Möbius do Brasil e 20 da ltália. As características dos perfis sociodemográfico, gestacional e neonatal foram coletadas a partir de entrevistas com os responsáveis dos pacientes e comparadas. Os pacientes foramsubmetidos aum exameoftalmológico emalformaçôes sistêmicas foramavaliadas. Resultados: O misoprostol foi usado no primeiro trimestre da gestação por $26(56,5 \%)$ mães brasileiras e por nenhuma italiana. A média de idade dos pacientes brasileiros com sequência de Möbius foi de 89,95 $\pm 7,79$ meses e dos italianos 102,6 $\pm 22,94$ meses $(P=0,6105$; teste de Mann-Whitney). Mães brasileiras tinham significantemente menor escolaridade ( $P=0,0002$; teste exato de Fisher) e mães italianas tinha relacionamentos estáveis mais frequentemente ( $P=0,0002$; teste exato de Fisher). A frequência de anormalidades oculares e sistêmicas foi semelhante entre as séries. Conclusão: Eventos adversos durante a gestação variaram entre os grupos. O uso de misoprostol pelas mães precocemente na gestação foi relatado apenas por mães brasileiras, que tinham menor escolaridade e status conjugal estável menos frequentemente. Achados clínicos foram semelhantes entre os grupos.
\end{abstract}

Descritores:SindromedeMöbius;Misoprostol/efeitos adversos; Transtornos damotilidade ocular; Educação; Gravidez; Brazil; Itália

\section{INTRODUCTION}

Möbius sequence is a rare congenital disease with a prevalence of between 0.0002 and $0.002 \%$ of births ${ }^{(1)}$. Minimum diagnostic criteria for this disease include congenital unilateral or bilateral facial and abducens nerve paresis. Other findings in these patients that are not part of the diagnostic criteria include the involvement of other cranial nerves, malformations of orofacial structures, reductive limb anomalies, and defects of the chest wall ${ }^{(2)}$.

Möbius sequence is usually sporadic, has a multifactor etiology, and affects both genders with equal frequency ${ }^{(1,3)}$. There are a few reports of familial occurrence, karyotypic changes, and autosomal dominant, autosomal recessive, and $X$-linked recessive inheritance ${ }^{(2,4-6)}$. In Brazil, several studies have shown a strong association between
Möbius sequence and misoprostol use during the first trimester of pregnancy ${ }^{(7-10)}$. Also, the patients' mother's socioeconomic status, cultural conditions, and environmental factors have been related to the genesis of this sequence ${ }^{(10-16)}$. Therefore, careful documentation of maternal events during pregnancy of children with this sequence can potentially further clarify its etiology $(7,9,14)$.

As a result of the low global frequency of Möbius sequence, most published studies are case reports involving individual criteria and protocols and include patients that are examined by different researchers ${ }^{(1)}$. The objective of the present study is to assess the socio-demographic characteristics, pregnancy, neonatal profile, and main ophthalmological and systemic findings of two series of Möbius sequence patients from Brazil and Italy, using the same diagnostic criteria and protocol.

\footnotetext{
Submitted for publication: January 24, 2012

Accepted for publication: April 10, 2012

Study was carried out at Fundação Altino Ventura (FAV).

Physician, Department of Pediatric Ophthalmology and Strabismus, Fundação Altino Ventura - FAV - Recife (PE), Brazil.

2 Physician, Department of Ophthalmology and Visual Science, University of Illinois, Chicago, USA.

${ }^{3}$ Physician, Neuro-ophthalmology Service, Head and Neck Department, University of Parma, Parma,

Italy.
${ }_{4}$ Physician, Department of Pediatric Surgery, Universidade Federal de Pernambuco - UFPE - Recife (PE), Brazil.

${ }^{5}$ Physician, Department of Scientific Research, Fundação Altino Ventura - FAV - Recife (PE), Brazil.

buco - HOPE - Recife (PE), Brazil.
}

Funding: No specific financial support was available for this study.

Disclosure of potential conflicts of interest: B.V.Ventura, None; M.T.Miller, None; D.Danda, None; A.Carta, None; C.T.Brandt, None; L.O.Ventura, None.

Correspondence address: Bruna Vieira Ventura. Fundação Altino Ventura. Rua da Soledade, 170 Recife (PE) - 50070-040 - Brazil - E-mail: brunaventuramd@gmail.com

This study was approved by the Ethics Committee (Investigational Review Board) of the Fundação Altino Ventura (Protocol 005/2007). 


\section{METHODS}

This investigation constitutes a prospective, observational crosssectional multicenter study. It was carried out after approval from the Ethics Committee/Investigational Review Board of the Fundação Altino Ventura (Protocol 005/2007) and followed the tenets of the Declaration of Helsinki. Study participants and their guardians were informed of the purpose of the study and gave written consent to participate before inclusion.

All patients with Möbius sequence cared for at the Fundação Altino Ventura and the Hospital de Olhos de Pernambuco, in Recife, Brazil, in 2007, were eligible for the study. In addition, all Möbius sequence patients that attended the "Italian Association of Möbius Syndrome Meeting", Italy, in April 2007, could participate. The diagnostic criteria for Möbius sequence included congenital unilateral or bilateral facial and abducens nerve paresis $s^{(2,10,16)}$.

Forty-six Brazilian patients with Möbius sequence participated in the study. Two-thirds of the cases were from a low-income population, cared for at the Fundação Altino Ventura, and one-third were patients of the Hospital de Olhos de Pernambuco, a private institution. In addition, 20 Italian Möbius sequence patients were assessed.

Two pediatric ophthalmologists conducted interviews with all mothers using a standard questionnaire that obtained information regarding marital status, education, pregnancy (maternal illness, exposure to medications, and other environmental agents), family history, and neonatal features. With regard to marital status, a stable relationship was considered a father and mother who lived in the same home.

Main ocular and systemic malformations were also evaluated. Ophthalmological examination consisted of morphologic data with special attention to eye movement limitations, eyelid fissure, abnormalities in horizontal movement, and Hirschberg measurements of eye alignment for near fixation. As some of the Möbius sequence patients had neurodevelopmental delay, isolated or associated with autism, ocular alignment was evaluated using the Hirschberg test to standardize these measurements among patients. Limitations of abduction associated with variable degrees of limited adduction and eye retraction on attempted adduction with narrowing of the palpebral fissure were considered findings of Duane retraction syndrome ${ }^{(2)}$. The minimum diagnostic criteria used for Poland-Möbius sequence were the aforementioned diagnostic criteria for Möbius sequence in addition to unilateral aplasia of the pectoralis major muscle and an ipsilateral hand anomaly, typically manifesting as brachysyndactyly ${ }^{(17)}$.

Statistical analysis was performed using SPSS for Windows (version 12.0, SPSS, Inc.). Normality was assessed using the Kolmogorov-Smirnov test. Continuous variables are expressed as the mean \pm standard error and the maximal and minimal values. Categorical variables are expressed as absolute and relative frequencies. Continuous data was compared using the Mann-Whitney test. Categorical data was compared using Fisher's exact test and $P<0.05$ was used to reject the null hypothesis.

\section{RESULTS}

The mean age of the Brazilian series was $89.95 \pm 7.79$ months (range: 3 to 216 months) and was $102.6 \pm 22.94$ months (range: 5 to 396 months; $P=0.6105 ;$ Mann-Whitney test) in the Italian series. In the Brazilian series, 25 (54.3\%) patients were male and in the Italian series 14 (70.0\%) were female, which did not reach a statistically significant difference ( $P=0.1068$; Fisher's exact test). Patient birth weight was similar in both groups; in the Brazilian series, the mean birth weight was $3.100 \pm 719.3$ grams (range: 620 to 4.051 grams), and in the Italian series it was $2.915 \pm 483.9$ grams (range: 2.000 to 4.050 grams; $P=0.097$; Mann-Whitney test).

Brazilian mothers had a significant lower education level than the Italian series ( $P=0.0002$; Fisher's exact test) (Table 1$)$. A statistically significant higher frequency of stable relationships was found in the Italian series ( $P=0.0002$; Fisher's exact test). There were no differences between the groups with respect to the mother's number of gestations (Brazilian: mean of $2.6 \pm 1.6$ gestations, range: 1 to 10; Italian: mean of $2.0 \pm 1.0$ gestations, range: 1 to $4 ; P=0.1721$; Mann-Whitney test). Parity was similar in both groups (Brazilian: mean of $2.3 \pm 1.4$ births, range: 1 to 9; Italian: mean of $1.8 \pm 0.9$ births, range: 1 to 4 ; $P=0.2726$; Mann-Whitney test). In the Brazilian group, 15 (32.6\%) mothers had previous abortions and in the Italian group, 4 had previous abortions (20.0\%).

There was a family history of Down syndrome in $4(8.7 \%)$ cases of the Brazilian series and in 3 (15.0\%) of the Italian series. In the Italian group, there was 1 (5.0\%) case of in vitro fertilization. There was 1 set of twins in the Brazilian group: 1 of the children was normal and the other presented with Möbius sequence associated with misoprostol use during pregnancy. There was no family history of consanguinity among the parents and there were no reports of additional cases of Möbius sequence in other family members in either group.

Twenty-six (56.5\%) Brazilian mothers used misoprostol early in pregnancy, in a single dose. The minimum total dose was $400 \mathrm{mcg}$ and the maximum $2800 \mathrm{mcg}$ (mean of $1060 \pm 640 \mathrm{mcg}$ ). The mean period of misoprostol use during pregnancy for abortion induction was $5.8 \pm 2.6$ weeks (range: 2 to 12 weeks). There was no history of tobacco, alcohol, or recreational drug use in either group. Adverse pregnancy events are summarized in table 2.

Common ophthalmological findings in both groups included variable levels of decreased abduction associated with adduction limitations. One (2.2\%) case in the Brazilian series and 2 (10.0\%) in the Italian series presented with features of Duane retraction syndrome. One (5.0\%) of said cases in the Italian series (a 33 year-old female) had hypogonadotropic hypogonadism. The most frequent strabismus

Table 1. Mother's sociodemographic profile of Möbius sequence patients from Brazil and Italy

\begin{tabular}{lrrr}
\hline & \multicolumn{2}{c}{ Groups } & \\
\cline { 2 - 3 } Profile & $\begin{array}{c}\text { Brazilian } \\
(\mathbf{n = 4 6 )}\end{array}$ & $\begin{array}{c}\text { Italian } \\
(\mathbf{n = 1 8 *})\end{array}$ & P value** \\
\hline $\begin{array}{l}\text { Mother's education level } \\
\quad \text { Secondary school }\end{array}$ & $38(82.6 \%)$ & $6(33.3 \%)$ & \\
$\quad$ University & $8(17.4 \%)$ & $12(66.7 \%)$ & 0.0002 \\
Marital status & & & \\
$\quad$ Single/divorced & $39(84.8 \%)$ & $5(27.8 \%)$ & \\
$\quad$ Stable relationship & $7(15.2 \%)$ & $13(72.2 \%)$ & 0.0002 \\
\hline
\end{tabular}

* = two patients in the Italian group did not provide education level and marital status ** Fisher's exact test

Table 2. Adverse pregnancy events in Möbius sequence patients from Brazil and Italy

\begin{tabular}{lcc}
\hline & \multicolumn{2}{c}{ Groups } \\
\cline { 2 - 3 } Adverse pregnancy events & $26(56.5 \%)$ & $0(0.0 \%)$ \\
\hline Misoprostol & $0(0.0 \%)$ & $3(15.0 \%)$ \\
Chorionic villus sampling & $3(6.5 \%)$ & $0(0.0 \%)$ \\
Dengue fever & $2(4.3 \%)$ & $0(0.0 \%)$ \\
Rubella & $0(0.0 \%)$ & $1(5.0 \%)$ \\
Rosella & $0(0.0 \%)$ & $2(10.0 \%)$ \\
Influenza & $0(0.0 \%)$ & $1(5.0 \%)$ \\
Anemia & & Italian (n=20) \\
\hline
\end{tabular}


diagnosis in both groups was esotropia (isolated or associated with a vertical deviation) (Figure 1). There were also cases of orthotropia and exotropia in both series (Table 3). Hypertropia was seen in 7 (15.2\%) Brazilian patients and in 1 (5.0\%) Italian patient. Unusual eye movement was detected in 1 (2.2\%) case in the Brazilian group, which presented as excyclotorsion during cover test and gaze-evoked nystagmus on upward gaze.

Characteristic mask-like face was evident in all cases. The incidence of limb abnormalities was similar in both groups ( $P=1.0000$; Fisher's exact test) (Table 4). Clubfoot was the most frequent abnormality, present in 26 (56.5\%) of the Brazilian cases and 10 (50.0\%) of the
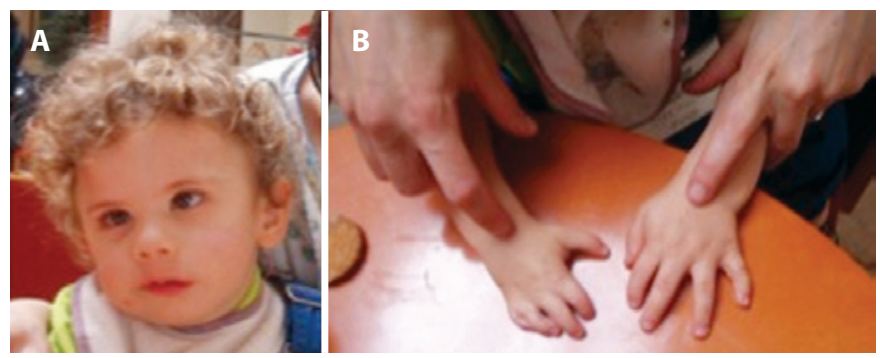

Figure 1. Italian patient with Poland-Möbius sequence. A) Mask-like facies and esotropia. B) Right brachysyndactyly.

Table 3. Horizontal ocular alignment in primary gaze position of patients with Möbius sequence from Brazil and Italy

\begin{tabular}{lccc}
\hline & \multicolumn{2}{c}{ Groups } \\
\cline { 2 - 3 } Ocular Motility & $\begin{array}{c}\text { Brazilian } \\
(\mathbf{n = 4 6 )}\end{array}$ & $\begin{array}{c}\text { Italian } \\
(\mathbf{n = 2 0 )}\end{array}$ & \multirow{2}{*}{$\boldsymbol{P}$ value $^{*}$} \\
\hline Orthotropia & $13(28.3 \%)$ & $8(40.0 \%)$ & $\mathbf{0 . 3 9 5 9}$ \\
Esotropia & $18(39.1 \%)$ & $8(40.0 \%)$ & 1.0000 \\
Exotropia & $8(17.4 \%)$ & $3(15.0 \%)$ & 1.0000 \\
\hline
\end{tabular}

${ }^{*}=$ Fisher's exact test

Table 4. Systemic anomalies in Möbius sequence patients from Brazil and Italy

\begin{tabular}{lccc}
\hline & \multicolumn{2}{c}{ Groups } & \\
\cline { 2 - 3 } Anomalies & $\begin{array}{c}\text { Brazilian } \\
(\mathbf{n}=\mathbf{4 6 )}\end{array}$ & $\begin{array}{c}\text { Italian } \\
(\mathbf{n}=\mathbf{2 0})\end{array}$ & \multicolumn{1}{c}{$\boldsymbol{P}$ value $^{*}$} \\
\hline Limb & $27(58.7 \%)$ & $12(60.0 \%)$ & 1.0000 \\
Club foot & $26(56.5 \%)$ & $10(50.0 \%)$ & 0.7886 \\
$\begin{array}{l}\text { Incomplete closure of the } \\
\text { eyelid }\end{array}$ & $23(50.0 \%)$ & $15(75.0 \%)$ & 0.1027 \\
Tongue & $20(43.5 \%)$ & $11(55.0 \%)$ & 0.4310 \\
\hline
\end{tabular}

* $=$ Fisher's exact test



Figure 2. Brazilian patient with Möbius sequence presenting upper and lower limb defects. A) Amputation defect in left upper limb. B) Bilateral feet deformity with amputation defects on the left foot.
Italian cases. Other associated limb defects seen in both groups were digit amputation, lower limb amputation, syndactyly, and agenesis of the radial bone (Figure 2). Some Brazilian and Italian patients had anatomical changes and fasciculation movement of the tongue due to XII cranial nerve involvement. Two (10.0\%) Italian patients and 16 (34.8\%) Brazilian patients had posteriorly rotated ears. Poland-Möbius sequence was present in 1 (2.2\%) case in the Brazilian group and in 2 (10.0\%) in the Italian group. The 3 Poland-Möbius sequence cases had ipsilateral brachysyndactyly; the Brazilian patient with Poland-Möbius sequence presented with dextrocardia and left Poland syndrome and 1 of the Italian cases with Poland-Möbius sequence had dextro and the other had left Poland syndrome. All 3 of these patients had partial absence of the upper costal cartilages.

\section{DISCUSSION}

The constellation of anomalies and dysfunctions commonly seen in Möbius sequence patients suggests that this disorder may result from several adverse, prenatal dysmorphogeneic events ${ }^{(14,18)}$. A common mechanism explaining the pathogenesis of Möbius sequence, Poland syndrome, Klippel-Feil syndrome, isolated terminal transverse limb defects, and Sprengel anomaly was proposed by Bouwes-Bavinck and Weaver: they suggest a transient vascular disruption of the early embryonic blood supply in the subclavian arteries, the vertebral arteries, and/or their branches ${ }^{(19)}$. This is a nonspecific event that can potentially be caused by various teratogens $s^{(1,2,14,19,20)}$. Exposure to teratogenic agents is a challenge that can be influenced by cultural factors, low population socio-economic level, high incidence of infectious and carential diseases, and self-medication habits associated with easy access to prescription drugs, which can result in new cases of birth defects ${ }^{(21)}$.

Misoprostol, a synthetic prostaglandin $\mathrm{E}_{1}$ analog, is frequently used for legal and illegal abortions in Brazil and other countries of South and Central America ${ }^{(7-10,22)}$. A previous study found that $60.7 \%$ of cases in which misoprostol was used to induce abortion occurred in unstable families or those of low socioeconomic status ${ }^{(10)}$. In the present study, the mothers from the Brazilian series presented with less stable relationships compared to the Italian cohort. In addition, the majority of the Brazilian cases were from a low-income population, with a significant lower education level.

Various cases of congenital malformations, including craniofacial defects and abdominal and limb anomalies, have been associated with the use of misoprostol during pregnancy ${ }^{(7-10)}$. The critical period of Möbius sequence pathogenesis is the first trimester, likely between gestational weeks four and eight ${ }^{(2)}$. Not surprisingly, the mean period of misoprostol use by the Brazilian mothers for abortive purposes in the current study was $5.8 \pm 2.6$ weeks post fertilization.

The reality of abortion varies from country to country. Abortion is a delicate issue, with sociodemographic, psychological, ethical, religious, and cultural implications ${ }^{(23)}$. In a study that included 25 individuals with Möbius sequence in Sweden, 6 mothers had a history of more than 1 spontaneous abortion and 1 threatened abortion (2). An increased rate of spontaneous abortions has been seen among the Italian population ${ }^{(24)}$. In the present study, there was no statistically significant difference in previous abortions among either group. Memory recall bias is an important factor in both series. This bias might be even more important in the Brazilian group, owing to the fact that abortion is illegal in Brazil, except in cases of rape or when the mother's life is in danger ${ }^{(9)}$. The absence or inadequate use of contraceptive methods by Brazilian women is also common thus contributing to a high incidence of alternative abortion methods $s^{(9,22)}$.

Some cases of Möbius sequence are associated with a history of significant adverse events during pregnancy ${ }^{(14-16,22)}$. In the Italian series, there is history of chorionic villus sampling performed in the first trimester of pregnancy in 3 cases (15.0\%). Firth et al. ${ }^{25)}$ reported terminal transverse-limb and cranial-nerve defects in infants exposed 
to early chorionic villus sampling. In a study that included 25 patients with Möbius sequence, there was 1 case associated with chorionic villus sampling in the ninth week of gestation ${ }^{(2)}$. Lipson et al. ${ }^{(14)}$ and Ghabrial et al. ${ }^{(15)}$, described events during pregnancy associated with Möbius sequence that included hyperthermia, electrical shock, threatened abortion, prolonged rupture of the membranes, and alcohol abuse.

Viral rosella and influenza infections were reported by some Italian mothers and rubella and dengue viral infection by some Brazilian mothers in the current case series; in 1 case from the Brazilian group, a mother reported both a rubella infection during the first trimester of pregnancy and also the use of $2800 \mathrm{mcg}$ of misoprostol as an abortifacient. Amaya et al. ${ }^{(16)}$ has reported 2 mothers with a non-specific viral infection and 1 with an unconfirmed rubella infection during the first trimester of pregnancy. However, a previous study from our group involving the Brazilian series and investigating the humoral immune response to dengue virus concluded that the dengue virus infection could not be considered as a factor involved in the genesis of Möbius sequence ${ }^{(26)}$.

Overall, the clinical features of patients from both groups were similar and consistent with previous studies ${ }^{(2,3,15,16)}$. The most common eye motility pattern detected in Möbius sequence patients is an apparent horizontal gaze paresis usually associated with marked abduction limitation and variable adduction deficits ${ }^{(27,28)}$. In the VI nerve nucleus there are neurons whose axons form the ipsolateral abducens nerve and interneurons whose axons reach the medial longitudinal fasciculus and ascend for innervating the subnucleus of the contralateral III nerve. This arrangement possibly explains how a lesion at the $\mathrm{VI}$ nerve nucleus can cause the ipsilateral horizontal gaze palsy ${ }^{(27)}$.

In the present series, there were straight eyes in the primary gaze position in $28.3 \%$ of the Brazilian cases and in $40.0 \%$ of the Italian cases, and exotropia in $17.4 \%$ of the Brazilian patients and $15.0 \%$ of the Italian cases. In another study that included 46 patients with Möbius sequence from Italy, there was orthotropia in $41.3 \%$ of the cases and exotropia in $8.7 \%$ in the primary gaze position ${ }^{(29)}$.

Three (4.5\%) of our cases had Duane retraction syndrome, which has been reported by other authors ${ }^{(3)}$. One of these cases had hypogonadotropic hypogonadism. In Möbius sequence, hypogonadotropic hypogonadism is an unusual finding, with only 8 previously reported cases in the literature ${ }^{(29)}$. In addition, 3 (4.5\%) cases presented PolandMöbius sequence. There was no association with misoprostol use during pregnancy in these patients. The Poland-Möbius sequence is the result of the rare overlapping of Poland and Möbius sequence, with an estimated prevalence of 1:500.000(30,31).

Malformations of the extremities were seen in $58.7 \%$ of the Brazilian patients and in $60.0 \%$ of the Italian patients, corroborating the findings of Verzijl et al..$^{(3)}$ The most common in our cases was clubfoot, present in almost half of the patients of both groups. Anatomic changes and impaired motility and fasciculation of the tongue occurred in $43.5 \%$ of the Brazilian cases and in $55.0 \%$ of the Italian cases. This finding was less frequent in the present study than in a Swedish study, which found tongue abnormalities in two-thirds of the patients ${ }^{(2)}$. In addition, both groups had cases with ear anomalies. In Möbius sequence patients, a defect of the elastic cartilage of the ear is typical and a posteriorly rotated ear is frequently seen ${ }^{(20)}$.

The present study has some limitations; the results can be affected by memory recall bias as, in some cases, the interviews were performed with the mothers after several years from the end of the pregnancy. Age in the Brazilian group ranged from three months to 16 years and in the Italian group from 5 months to 33 years. Among Brazilian mothers there is evidence of emotional suffering in recalling the details of drug use (misoprostol) as an abortifacient.

In conclusion, this study provides more insight into pregnancy factors, family history, and malformations of a series of Möbius sequence patients from Brazil and from Italy. The sociodemographic and gestational profiles of patients from the two countries differed. Mothers from the Brazilian series had a lower level of education and more unstable marital statuses. Adverse events during pregnancy varied between the groups, due to environmental factors, and sociodemographic and cultural aspects. Möbius sequence was associated with misoprostol use during pregnancy as an abortion method in more than half of the pregnancies of the Brazilian series and in none of the Italian. Only in the Italian series was chorionic villus sampling implemented during pregnancy. Viral infection was reported during the gestational period in both groups. Patients presented with wide variability of ocular, somatoskeletal, and cranial nerve abnormalities, the prevalence of which were similar in both groups.

\section{REFERENCES}

1. Briegel W. Neuropsychiatric findings of Möbius sequence - a review. Clin Genet. 2006; 70(2):91-7. Review.

2. Strömland K, Sjögreen L, Miller M, Gillberg C, Wentz E, Johansson M, et al. Möbius sequence: a Swedish multidiscipline study. Eur J Paediatr Neurol. 2002:6(1):35-45.

3. Verzijl HT, van der Zwaag B, Cruysberg JR, Padberg GW. Möbius syndrome redefined: a syndrome of rhombencephalic maldevelopment. Neurology. 2003;61(3):327-33

4. McKusick VA. Mendelian inheritance in man: catalog of autosomal dominant, autosomal recessive, and X-linked phenotypes. $8^{\text {th }}$ ed. Baltimore: Johns Hopkins University Press; 1988.

5. Baraitser M. Genetics of Möbius syndrome. J Med Genet. 1977;14(6):415-7.

6. Kremer H, Kuyt LP, van den Helm B, van Reen M, Leunissen JA, Hamel BC, et al. Localization of a gene for Möbius syndrome to chromosome $3 q$ by linkage analysis in a Dutch family. Hum Mol Genet. 1996;5(9):1367-71.

7. Gonzalez CH, Marques-Dias MJ, Kim CA, Sugayama SM, Da Paz JA, Huson SM, et al. Congenital abnormalities in Brazilian children associated with misoprostol misuse in first trimester of pregnancy. Lancet. 1998;351(9116):1624-7. Comment in Lancet. 1999;353(9155):843-4. Lancet. 1998;352(9124):323.

8. Vargas FR, Schuler-Faccini L, Brunoni D, Kim C, Meloni VF, Sugayama SM, et al. Prenatal exposure to misoprostol and vascular disruption defects: a case-control study. Am J Med Genet. 2000;95(4):302-6.

9. Boudoux DD, Matos MAG, Gonçalves ED, Rocha M, Ventura LO, Hinrichsen SL. Síndrome de Moebius relacionada à ameaça de abortamento. Rev Bras Oftalmol. 2000; 59(3):173-7.

10. Sena M, Ventura L, Miller M, Almeida HC, Leal DB, Brandt CT. Perfil sociodemográfico e gestacional de pacientes com a sequência de Möbius. An Fac Med Univ Fed Pernamb. 2003;48(1):36-41

11. Kankirawatana P, Tennison MB, D'Cruz O, Greenwood RS. Möbius syndrome in infant exposed to cocaine in utero. Pediatr Neurol. 1993;9(1):71-2.

12. Elsahy NI. Moebius syndrome associated with the mother taking thalidomide during gestation. Case report. Plast Reconstr Surg. 1973;51(1):93-5.

13. Courtens W, Vamos $E$, Hainaut $M$, Vergauwen $P$. Moebius syndrome in an infant exposed in utero to benzodiazepines. J Pediatr. 1992;121(5 Pt 1):833-4. Comment on J Pediatr. 1989;114(1):126-31.

14. Lipson AH, Webster WS, Brown-Woodman PD, Osborn RA. Moebius syndrome: animal model-human correlations and evidence for a brainstem vascular etiology. Teratology. 1989:40(4):339-50. Review.

15. Ghabrial R, Versace P, Kourt G, Lipson A, Martin F. Möbius' syndrome: features and etiology. J Pediatr Ophthalmol Strabismus. 1998;35(6):304-311; quiz 327-8.

16. Amaya LG, Walker J, Taylor D. Mobius syndrome: a study and report of 18 cases. Binocul Vis Q. 1990;5(3):119-32.

17. Poland A. Deficiency of the pectoralis muscles. Guy's Hosp Rep. 1841;6:191-3.

18. D'Cruz OF, Swisher CN, Jaradeh S, Tang T, Konkol RJ. Möbius syndrome: evidence for a vascular etiology. J Child Neurol. 1993;8(3):260-5.

19. Bavinck JN, Weaver DD. Subclavian artery supply disruption sequence: hypothesis of a vascular etiology for Poland, Klippel-Feil, and Möbius anomalies. Am J Med Genet. 1986;23(4):903-18.

20. Kuklík M. Poland-Möbius syndrome and disruption spectrum affecting the face and extremities: a review paper and presentation of five cases. Acta Chir Plast. 2000; 42(3):95-103.

21. Schüler-Faccini L, Leite JCL, Sanseverino MTV, Peres RM. Avaliação de teratógenos na população brasileira. Ciênc Saúde Coletiva. 2002;7(1):65-71.

22. Pastuszak AL, Schüler L, Speck-Martins CE, Coelho KE, Cordello SM, Vargas F, et al. Use of misoprostol during pregnancy and Möbius' syndrome in infants. N Engl J Med. 1998;338(26):1881-5. Comment in N Engl J Med. 1998;339(21):1553-4.

23. Coêlho HL, Teixeira AC, Cruz M de F, Gonzaga SL, Arrais PS, Luchini L, et al. Misoprostol: the experience of women in Fortaleza, Brazil. Contraception. 1994:49(2):101-10.

24. Stranges M. [Risks associated with childbearing postponement: the relationship between increased mean maternal age and spontaneous abortions in Italy]. Ig Sanita Pubbl. 2007;63(2):163-78. Italian. 
25. Firth HV, Boyd PA, Chamberlain P, McKenzie IZ, Lindenbaum RH, Huson SM. Severe limb abnormalities after chorion villus sampling at 55-66 days' gestation. Lancet. 1991;337(8744):762-3. Comment in Lancet. 1991;337(8748):1038-9. Lancet. 1991; 337(8749):1091-2. Lancet. 1991;337(8754):1422-4. Lancet. 1992;339(8784):66.

26. Gadelha DNB, Ventura BV, Ventura LMVO, Miller MT, Cordeiro MT, Castro CMMB. Resposta humoral ao vírus dengue em mães/filhos: relação com a sequência de Möbius. Arq Bras Oftalmol. 2009;72(3):327-31.

27. de Souza-Dias CR, Goldchmit M. Further considerations about the ophthalmic features of the Möbius sequence, with data of 28 cases. Arq Bras Oftalmol. 2007;70(3):451-7.

28. Santos LPF, Ventura LMVO, Almeida HC, Miller M, Colier AC. Achados oftalmológicos em 28 crianças portadoras da sequência de Möebius. Arq Bras Oftalmol. 2004;67(4): 591-5.

29. Carta A, Mora P, Neri A, Favilla S, Sadun AA. Ophthalmologic and systemic features in möbius syndrome an Italian case series. Ophthalmology. 2011;118(8):1518-23.

30. Larrandaburu M, Schüler L, Ehlers JA, Reis AM, Silveira EL. The occurrence of Poland and Poland-Moebius syndromes in the same family: further evidence of their genetic component. Clin Dysmorphol. 1999;8(2):93-9.

31. Puvabanditsin S, Garoow E, Augustin G, Titapiwatanakul R, Kuniyoshi KM. Poland-Möbius syndrome and cocaine abuse: a relook at vascular etiology. Pediatr Neurol. 2005; 32(4):285-7.

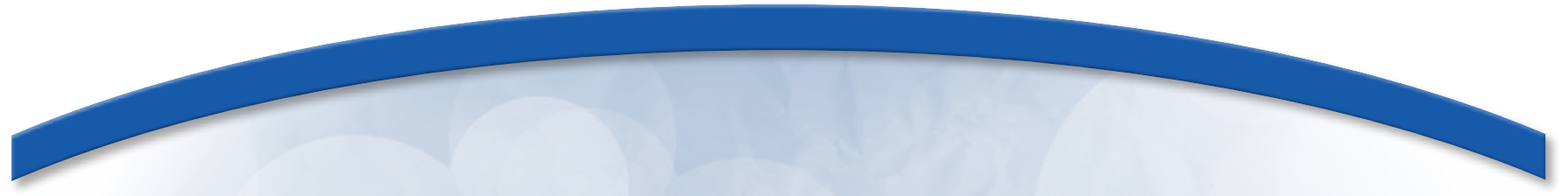

XXIV SIDUO 2012 Congress

Societas Internationalis pro

Diagnostica Ultrasonica in Ophthalmologia

\section{7 a 11 de dezembro de 2012}

\section{Hotel Renaissance}

São Paulo (SP)

\section{Informações:}

Site: www.siduo2012.com 